\title{
Multiscale Metal Oxide Particles to Enhance Photocatalytic Antimicrobial Activity against Escherichia coli and M13 Bacteriophage under Dual Ultraviolet Irradiation
}

\author{
Su-Eon Jin ${ }^{1, *}$ and Hyo-Eon Jin ${ }^{2, *(1)}$ \\ 1 Research Institute for Medical Sciences, College of Medicine, Inha University, Incheon 22212, Korea \\ 2 College of Pharmacy, Ajou University, Suwon 16499, Korea \\ * Correspondence: jins@inha.ac.kr (S.-E.J.); hjin@ajou.ac.kr (H.-E.J.)
}

check for updates

Citation: Jin, S.-E.; Jin, H.-E. Multiscale Metal Oxide Particles to Enhance Photocatalytic Antimicrobial Activity against Escherichia coli and M13 Bacteriophage under Dual Ultraviolet Irradiation. Pharmaceutics 2021, 13, 222. https://doi.org/ $10.3390 /$ pharmaceutics 13020222

Academic Editor: Clive Prestidge Received: 29 November 2020 Accepted: 1 February 2021 Published: 6 February 2021

Publisher's Note: MDPI stays neutral with regard to jurisdictional claims in published maps and institutional affiliations.

Copyright: (c) 2021 by the authors. Licensee MDPI, Basel, Switzerland. This article is an open access article distributed under the terms and conditions of the Creative Commons Attribution (CC BY) license (https:/ / creativecommons.org/licenses/by/ $4.0 /)$.

\begin{abstract}
Antimicrobial activity of multiscale metal oxide (MO) particles against Escherichia coli (E. coli) and M13 bacteriophage (phage) was investigated under dual ultraviolet (UV) irradiation. Zinc oxide $(\mathrm{ZnO})$, magnesium oxide $(\mathrm{MgO})$, cuprous oxide $\left(\mathrm{Cu}_{2} \mathrm{O}\right)$, and cupric oxide $(\mathrm{CuO})$ were selected as photocatalytic antimicrobials in MO particles. Physicochemical properties including morphology, particle size/particle size distribution, atomic composition, crystallinity, and porosity were evaluated. Under UV-A and UV-C irradiation with differential UV-C intensities, the antimicrobial activity of MO particles was monitored in E. coli and phage. MO particles had nano-, micro- and nano- to microscale sizes with irregular shapes, composed of atoms as ratios of chemical formulae and presented crystallinity as pure materials. They had wide-range specific surface area levels of $0.40-46.34 \mathrm{~m}^{2} / \mathrm{g}$. MO particles themselves showed antibacterial activity against $E$. coli, which was the highest among the $\mathrm{ZnO}$ particles. However, no viral inactivation by $\mathrm{MO}$ particles occurred in phage. Under dual UV irradiation, multiscale $\mathrm{ZnO}$ and $\mathrm{CuO}$ particles had superior antimicrobial activities against $E$. coli and phage, as mixtures of nano- and microparticles for enhanced photocatalytic antimicrobials. The results showed that the dual UV-multiscale MO particle hybrids exhibit enhanced antibiotic potentials. It can also be applied as a next-generation antibiotic tool in industrial and clinical fields.
\end{abstract}

Keywords: multiscale metal oxide particles; dual UV; photocatalytic antimicrobials; E. coli; M13 bacteriophage

\section{Introduction}

Metal oxide (MO) particles have been highlighted as nano-antibiotics against pathogenic microorganisms for enhanced disinfection [1,2]. They exhibit wide-spectrum antimicrobial activities against bacteria as well as viruses, and even against antibiotic-resistant microorganisms [3,4]. The antimicrobial functions of MO particles are displayed by their adsorption potentials to biomembranes of microorganisms, owing to their surface properties [5,6]. Under ultraviolet (UV) irradiation, reactive oxygen species (ROS) produced by $\mathrm{MO}$ particles induce germicidal toxicity of nucleic acid breaks in microorganisms. In MO particles, biological and toxicological responses against microorganisms are primarily mediated by physicochemical characteristics under non-UV or UV irradiation. Specifically, their physicochemical characteristics including morphology, particle size, atomic composition, crystallinity, and porosity are the major factors to affect the responses of microorganisms inducing antimicrobial actions [7]. Among the properties of MO particles, their photocatalytic antimicrobial activity of $\mathrm{MO}$ particles can be mainly affected by particle size variation $[8,9]$. Therefore, the antimicrobial activity of multiscale MO particles ranging from nano- to microsized levels should be screened.

Particle size variety has been studied in photocatalytic antimicrobial activity of MO particles for enhanced disinfection $[7,10]$. In the case of MO nanoparticles (NPs, <100 nm) 
including zinc oxide $(\mathrm{ZnO})$, zinc titanate $\left(\mathrm{ZnTiO}_{3}\right)$, magnesium oxide $(\mathrm{MgO})$, and cupric oxide $(\mathrm{CuO})$ used as photocatalysts, they showed enhanced antimicrobial activity and blocked bacterial regrowth as compared to UV irradiation alone [11,12]. On the contrary, low antimicrobial activities were detected in MO microparticles (MPs, $>100 \mathrm{~nm}$ ) against Escherichia coli and Staphylococcus aureus, which ranged from 0.1 to $0.8 \mu \mathrm{m}$ in diameter with specific surface area of $0.85-26.0 \mathrm{~m}^{2} / \mathrm{g}$ [9]. However, the photocatalytic disinfection potential of MO MPs can be improved in ROS generation under UV irradiation based on the porosity via multiple scattering phenomena for enhanced mass transfer and exchange rate $[13,14]$. In addition to MO NPs or MPs alone, photocatalytic antimicrobial activity of multiscale MO particles can be monitored as mixtures of MO NPs and MPs.

The hybridization of MO particles to dual UV, UV-A (315-400 nm) and UV-C $(100-280 \mathrm{~nm})$, is one of the most ecofriendly disinfection techniques, which facilitates wide-spectrum antimicrobial activity based on combined wavelengths $[15,16]$. Although UV-A is used for the removal of harmful insects and worms after a long exposure [17], UV-C is a powerful germicidal wavelength range, specifically $253 \mathrm{~nm}$, for pathogenic microorganism disinfection [18]. Enhanced antibiotic potential of dual UV is described by a combination of MO NPs as photocatalysts, compared to single UV or antibacterial agent alone $[19,20]$. A dual UV and photocatalyst hybrid system can prevent regrowth or reactivation of bacteria and viruses after single UV irradiation, killing antibiotic-resistant microorganisms.

In the present study, we investigated whether multiscale MO particles, a mixture of MO NPs and MPs could have an enhanced antimicrobial activity coupled with non$\mathrm{UV}$ or $\mathrm{UV}$ irradiations. $\mathrm{ZnO}, \mathrm{MgO}, \mathrm{Cu}_{2} \mathrm{O}$, and $\mathrm{CuO}$ particles were selected to screen antimicrobial activity. Physicochemical characteristics of multiscale $\mathrm{MO}$ particles were evaluated in terms of morphology, particle size/particle size distribution, atomic composition, crystallinity, and porosity. Antimicrobial activity test was performed in E. coli and M13 bacteriophage (phage), which were used as model microorganisms. The mechanisms underlying antimicrobial action were further discussed.

\section{Materials and Methods}

\subsection{Chemical Reagents}

MO particles consisting of $\mathrm{ZnO}$ [ZnO-(1) (powder, $<5 \mu \mathrm{m}, 99.9 \%$ ) and $\mathrm{ZnO}-(2)$ (nanopowder, $<100 \mathrm{~nm}$ )], MgO [MgO-(1) (calcined, $\geq 97.0 \%$ ) and MgO-(2) (fused, 150-325 mesh, $\geq 95 \%$ )], $\mathrm{Cu}_{2} \mathrm{O}$ (powder, $\leq 7 \mu \mathrm{m}, 97 \%$ ), and $\mathrm{CuO}$ (powder, $<10 \mu \mathrm{m}, 98 \%$ ) were purchased from Sigma-Aldrich (St. Louis, MO, USA). Absolute ethanol (99.9\%) and isopropyl alcohol were obtained from Sigma-Aldrich (USA). Luria-Bertani (LB) medium and agar were obtained from BD Biosciences (Franklin Lakes, NJ, USA). All chemicals were of reagent grade and used without further purification. Deionized water was obtained using a water purification system (Milli-Q, Millipore, Billerica, MA, USA).

\subsection{Field Emission-Scanning Electron Microscopy (FE-SEM) with Energy-Dispersive X-ray Spectroscopy (EDS)}

Morphologies of MO particles were monitored using a FE-SEM (JSM-7100F, Jeol Ltd., Tokyo, Japan). It was operated at an acceleration voltage of $15.0 \mathrm{kV}$. Magnifications were set at 5000-50,000. Samples were investigated after platinum coating. EDS analysis was also performed at three points on the surface of MO particles to quantitatively determine the compositions of elements.

\subsection{Powder X-ray Diffractometry (PXRD)}

The crystallinities of MO particles were analyzed using a PXRD. The PXRD patterns of the particles were recorded from 20 to $802 \theta$ (degree, $^{\circ}$ ) using a high resolution X-ray diffractometer (HR XRD, SmartLab, Rigaku, Tokyo, Japan) with CuK $\alpha$ radiation. The data were collected and analyzed in SmartLab Studio (Rigaku). 


\subsection{Brunauer-Emmett-Teller (BET) Analysis}

Mesopores of MO particles were analyzed from nitrogen adsorption-desorption isotherms using a Qudrasorb SI (Quantachrome Instruments, Boynton Beach, FL, USA). Each sample was weighed at 1.0-3.0 g. Experimental results of specific surface area, total pore volume, and average pore diameter were calculated using ASiQwin software (Quantachrome Instruments) based on the BET theory.

\subsection{Dual UV Irradiation in Collimated Beam Device (CBD)}

CBD was prepared using a dual UV lamp of UV-A and UV-C (ECOSET Co., Ltd., Ansan, Korea), controlling UV-C intensity by lamp surface coating [11]. The electronic controller for $40 \mathrm{~W} / \mathrm{m}^{2}$ was connected to CBD. Fans were attached at both ends to minimize the heat generation of the UV lamp. UV dose $\left(\mathrm{J} / \mathrm{m}^{2}\right)$ was calculated from the intensity $\left(\mathrm{W} / \mathrm{m}^{2}\right)$ of the UV lamp and exposure time (s) after obtaining UV intensity using a spectrometer (Jaz System, Ocean Optics, Inc., Orlando, FL, USA) with software (Spectra Suite, Ocean Optics, Inc.).

\subsection{Antimicrobial Activity Test in E. coli and Phage}

Antimicrobial activities of the MO particles and dual UV-MO particle hybrids were investigated in E. coli and phage as the model microorganisms of bacteria and viruses, respectively. MO particles or dual UV alone were used as controls. Dispersed MO particles in water $(1 \mathrm{mg} / \mathrm{mL})$ were added to E. coli $\left(10^{4}\right.$ colony forming unit, CFU). After incubation in the dark for $30 \mathrm{~min}$, the samples $(1 \mathrm{~mL})$ were collected, added to LB/agar medium, and poured into plates. The resultant plate samples were incubated in the dark at $37^{\circ} \mathrm{C}$ overnight. In the case of phage, $\mathrm{MO}$ particles in water $(1 \mathrm{mg} / \mathrm{mL})$ were mixed with phage ( $10^{4}$ plaque forming units, PFU) and incubated for $30 \mathrm{~min}$. Then, $100 \mu \mathrm{L}$ of the samples were collected and incubated with overnight cultured bacteria at room temperature for $60 \mathrm{~min}$. After mixing the top agars with those, they were poured onto LB/isopropyl $\beta$-d-1-thiogalactopyranoside (IPTG) / 5 -bromo-4-chloro-3-indolyl- $\beta$-D-galactopyranoside (X-gal) plates and incubated at $37^{\circ} \mathrm{C}$ overnight. For photocatalytic antimicrobial activity, MO particles were irradiated under dual UV for 10 or $30 \mathrm{~s}$ while they were incubated with $E$. coli or phage for $30 \mathrm{~min}$. After incubation, each sample for E. coli or phage was collected and processed as mentioned above. The colonies and phage plaques were counted using Image J (NIH) after their images were obtained.

\subsection{Statistical Analysis}

The results are expressed as the means \pm standard deviation. The statistical differences among the groups were tested using Student's $t$-test. A $p$-value less than 0.05 was considered to be statistically significant.

\section{Results}

\subsection{Morphology and Particle Size Distribution}

$\mathrm{MO}$ particles of $\mathrm{ZnO}, \mathrm{MgO}, \mathrm{Cu}_{2} \mathrm{O}$, and $\mathrm{CuO}$ formed various irregular shapes such as needles, rods, and spheres to develop additive particle clusters with interparticular pores (Figure 1). ZnO-(1) (Figure 1A) and $\mathrm{ZnO}-(2)$ (Figure 1B) particles had shapes similar to needles or rods. MgO-(1) particles (Figure 1C) had nanoscale-sized shapes of spheres or cubes, which generated submicron-sized spherical clusters. However, $\mathrm{MgO}-(2)$ particles (Figure 1D) showed cuboidal crystalline shape. $\mathrm{Cu}_{2} \mathrm{O}$ (Figure 1E) and $\mathrm{CuO}$ (Figure 1F) particles were mixtures of irregular shaped NPs and had curved or angular particles of submicron size. 

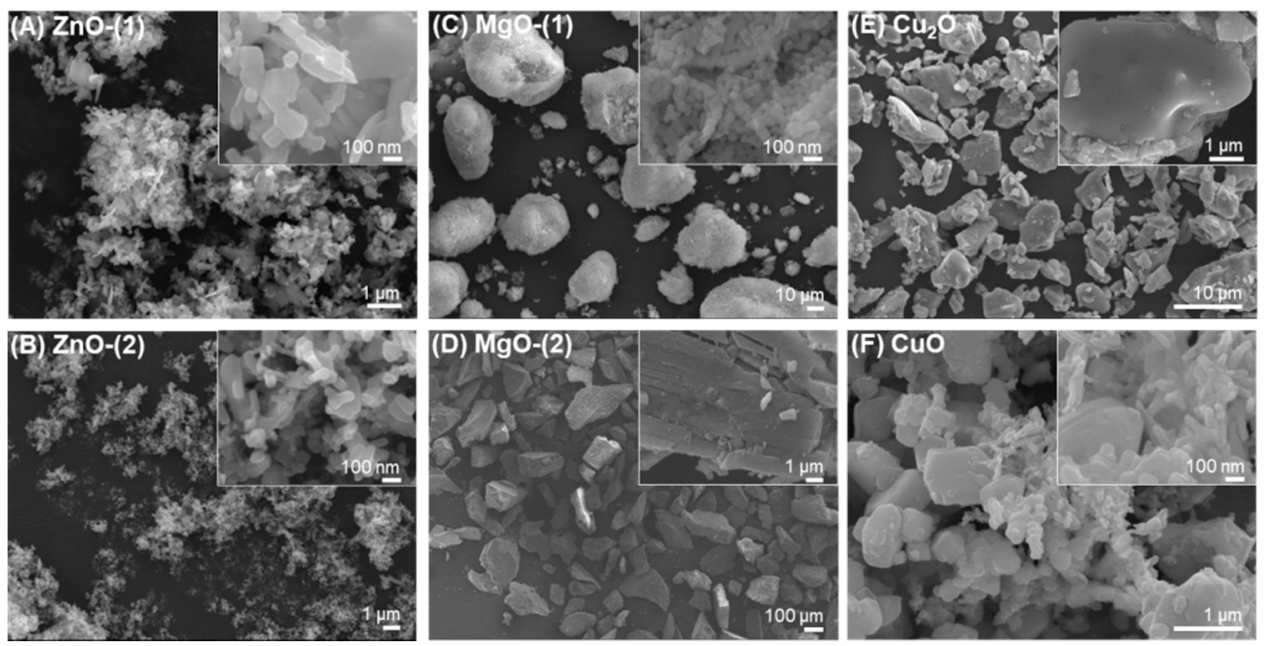

Figure 1. FE-SEM images of metal oxide (MO) particles: (A) $\mathrm{ZnO}-(1),(\mathbf{B}) \mathrm{ZnO}-(2),(\mathbf{C}) \mathrm{MgO}-(1),(\mathbf{D}) \mathrm{MgO}-(2),($ E) $\mathrm{Cu} 2 \mathrm{O}$, and (F) $\mathrm{CuO}$.

In particle size distribution, MO particles had nano- to microscale sizes of $84.6 \mathrm{~nm}-0.706 \mu \mathrm{m}$ for $\mathrm{ZnO}-(1)$ and $76.9-153.8 \mathrm{~nm}$ for $\mathrm{ZnO}-(2)$ particles [ZnO-(1) > $\mathrm{ZnO}-(2)$ ]; 50-76.9 nm for MgO-(1) and 8.0-138 $\mu \mathrm{m}$ for MgO-(2) particles [MgO-(1) < $\mathrm{MgO}-(2)]$; $1.2-6.0 \mu \mathrm{m}$ for $\mathrm{Cu}_{2} \mathrm{O}$ and $50.0 \mathrm{~nm}-0.577 \mu \mathrm{m}$ for $\mathrm{CuO}$ particles $\left(\mathrm{Cu}_{2} \mathrm{O} \geq \mathrm{CuO}\right)$. Specifically, $\mathrm{ZnO}-(1)$ and $\mathrm{CuO}$ particles were multiscale mixtures of NPs and MPs. ZnO-(2) and MgO-(1) particles were NPs, and $\mathrm{MgO}-(2)$ and $\mathrm{Cu}_{2} \mathrm{O}$ particles were MPs. However, in $\mathrm{MgO}$ particles, $\mathrm{MgO}-(1)$ particles generated particle clusters ranged from 28 to $54 \mu \mathrm{m}$, which were smaller than $\mathrm{MgO}-(2)$ particles $(>100 \mu \mathrm{m})$. In a hydrodynamic environment, $\mathrm{MO}$ particles generated large aggregates $(<100 \mathrm{~nm},>100 \mu \mathrm{m})$ in a number-weighted distribution mode (Figure S1). In $\mathrm{ZnO}$ and $\mathrm{MgO}$ particles, each particle size of aggregate was conversely displayed, compared to individual particle size, due to the differential particle aggregate formation capacity [ZnO-(1) $<\mathrm{ZnO}-(2)$; $\mathrm{MgO}-(1)>\mathrm{MgO}-(2)]$ (Table S1). In the case of $\mathrm{Cu}_{2} \mathrm{O}$ and $\mathrm{CuO}$ particles, their aggregate sizes were similar to each other $\left(\mathrm{Cu}_{2} \mathrm{O} \approx \mathrm{CuO}\right)$.

\subsection{Atomic Compositions}

In EDS spectra (Figure S2), atomic compositions of MO particles were matched for pure chemical formula (Table 1). ZnO particles included 78.5-81.9\% of $\mathrm{Zn}$ and $18.1-21.4 \%$ of $\mathrm{O} . \mathrm{MgO}$ particles contained $61.1-63.5 \%$ of $\mathrm{Mg}$ and $36.5-38.9 \%$ of $\mathrm{O} . \mathrm{Cu}_{2} \mathrm{O}$ and $\mathrm{CuO}$ particles had $88.7 \%$ of $\mathrm{Cu}$ and $11.3 \%$ of $\mathrm{O}$ for $\mathrm{Cu}_{2} \mathrm{O}$, and $75.9 \%$ of $\mathrm{Cu}$ and $24.1 \%$ of $\mathrm{O}$ for $\mathrm{CuO}$. Atomic compositions were similar in all the $\mathrm{MO}$ particles, irrespective of morphology and particle size. Although $\mathrm{ZnO}-(1)$ particles contained an $\mathrm{Al}$ contaminant of less than $0.05 \%$ in EDS, no Al contaminants were detected in XPS. Binding energy of $\mathrm{ZnO}-(1)$ particles were detected at 1022 and $1045 \mathrm{eV}$ for Zn2p and $531 \mathrm{eV}$ for O1s (Figure S3).

Table 1. Atomic compositions of metal oxide (MO) particles.

\begin{tabular}{cccccc}
\hline MO Particles & $\mathbf{Z n}$ & $\mathbf{A l}$ & $\mathbf{M g}$ & $\mathbf{C u}$ & O \\
\hline $\mathrm{ZnO}-(1)$ & $78.5 \pm 1.6$ & $0.01 \pm 0.02$ & - & - & $21.4 \pm 1.6$ \\
$\mathrm{ZnO}-(2)$ & $81.9 \pm 0.6$ & - & - & - & $18.1 \pm 0.6$ \\
$\mathrm{MgO}-(1)$ & - & - & $61.1 \pm 1.4$ & - & $38.9 \pm 1.4$ \\
$\mathrm{MgO}-(2)$ & - & - & $63.5 \pm 2.1$ & - & $36.5 \pm 2.1$ \\
$\mathrm{Cu}_{2} \mathrm{O}$ & - & - & - & $88.7 \pm 1.2$ & $11.3 \pm 1.2$ \\
$\mathrm{CuO}$ & - & - & - & $75.9 \pm 0.3$ & $24.1 \pm 0.3$ \\
\hline
\end{tabular}

\subsection{Crystallinity}

PXRD patterns described the high crystallinity of MO particles suggesting that they were pure materials with negligible impurities (Figure 2). MO particles showed hexagonal 
wurtzite structures for $\mathrm{ZnO}-(1)$ and $\mathrm{ZnO}-(2)$ particles (ICDD 01-080-0075, Figure 2A,B), cubic lattices for MgO-(1) (ICDD 01-071-3631, Figure 2C) and MgO-(2) (ICDD 00-045-0946, Figure 2D) particles, cubic polycrystalline for $\mathrm{Cu}_{2} \mathrm{O}$ particles (ICDD 01-071-3645, Figure 2E), and monoclinic phase for $\mathrm{CuO}$ particles (ICDD 01-089-5898, Figure 2F).
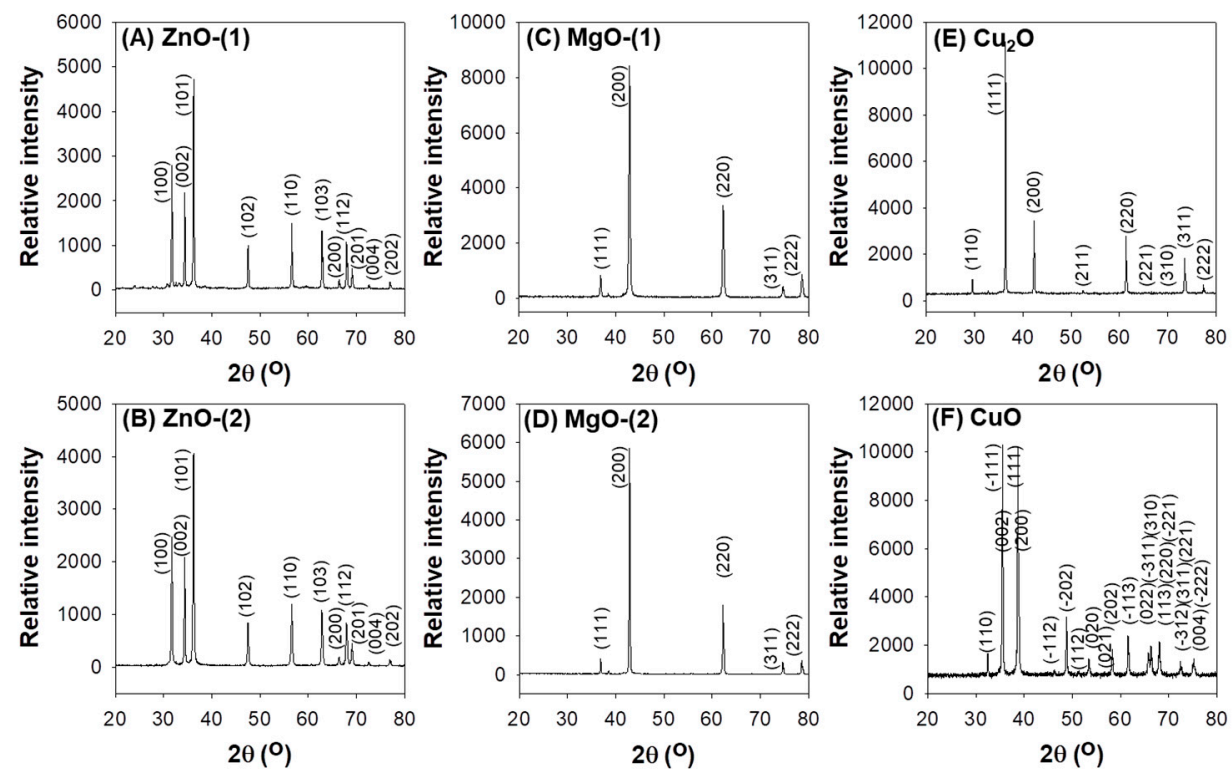

Figure 2. PXRD patterns of metal oxide (MO) particles: (A) $\mathrm{ZnO}-(1)$, (B) $\mathrm{ZnO}-(2)$, (C) $\mathrm{MgO}-(1)$, (D) $\mathrm{MgO}-(2),\left(\right.$ E) $\mathrm{Cu}_{2} \mathrm{O}$, and (F) $\mathrm{CuO}$.

\subsection{Porosity}

Surface area, pore volume, and pore size of MO particles are listed in Table 2. Surface area levels were the highest in $\mathrm{ZnO}-(1)$ particles $\left(46.34 \mathrm{~m}^{2} / \mathrm{g}\right)$, and the lowest in $\mathrm{MgO}-(2)$ particles $\left(0.3997 \mathrm{~m}^{2} / \mathrm{g}\right)$ in order of $\mathrm{ZnO}-(1), \mathrm{MgO}-(1), \mathrm{ZnO}-(2), \mathrm{CuO}_{1} \mathrm{Cu}_{2} \mathrm{O}$, and $\mathrm{MgO}-(2)$ particles. In pore volume levels, $\mathrm{MgO}-(1)$ particles showed the highest $(0.2883 \mathrm{cc} / \mathrm{g})$ and $\mathrm{MgO}-(2)$ particles had the lowest $(0.003593 \mathrm{cc} / \mathrm{g})$ in order of $\mathrm{MgO}-(1), \mathrm{ZnO}-(1), \mathrm{ZnO}-(2)$, $\mathrm{CuO}, \mathrm{Cu}_{2} \mathrm{O}$, and $\mathrm{MgO}-(2)$ particles. Mesopore size levels of $\mathrm{MO}$ particles ranged from 9.540 to $45.76 \mathrm{~nm}$ in order of MgO-(1) $(45.76 \mathrm{~nm}), \mathrm{MgO}-(2)(35.96 \mathrm{~nm}), \mathrm{ZnO}-(2)(29.86 \mathrm{~nm})$, $\mathrm{Cu}_{2} \mathrm{O}(25.80 \mathrm{~nm}), \mathrm{CuO}(21.02 \mathrm{~nm})$, and $\mathrm{ZnO}-(1)(9.540 \mathrm{~nm})$ particles.

Table 2. Surface characteristics of metal oxide (MO) particles.

\begin{tabular}{cccc}
\hline MO Particles & $\begin{array}{c}\text { Surface Area } \\
\left(\mathbf{m}^{\mathbf{2}} / \mathbf{g}\right)\end{array}$ & $\begin{array}{c}\text { Pore Volume } \\
(\mathbf{c c} / \mathbf{g})\end{array}$ & $\begin{array}{c}\text { Pore Size } \\
(\mathbf{n m})\end{array}$ \\
\hline $\mathrm{ZnO}-(1)$ & 46.34 & 0.1105 & 9.540 \\
$\mathrm{ZnO}-(2)$ & 11.58 & 0.08644 & 29.86 \\
& & & \\
$\mathrm{MgO}-(1)$ & 25.20 & 0.2883 & 45.76 \\
$\mathrm{MgO}-(2)$ & 0.3997 & 0.003593 & 35.96 \\
$\mathrm{Cu}$ & - & - \\
$\mathrm{CuO}$ & $0.1090^{1}$ & 0.003893 & 25.80 \\
\hline
\end{tabular}

${ }^{1}$ Krypton

\subsection{Antimicrobial Activity of MO Particles}

3.5.1. Antibacterial Activity against E. coli

Antimicrobial effect of $\mathrm{MO}$ particles against E. coli was investigated without UV irradiation (Figure 3). In $\mathrm{ZnO}$ particles, both $\mathrm{ZnO}-(1)$ and $\mathrm{ZnO}-(2)$ particles showed a dosedependent antibacterial activity against $E$. coli at $0.1-1.0 \mathrm{mg} / \mathrm{mL}$ (Figure 3A). Figure 3B 
displays the representative plate images after antibacterial activity test of $\mathrm{ZnO}-(2)$ particles against E. coli. Although $\mathrm{MgO}$ (Figure $3 \mathrm{C}, \mathrm{D}$ ), $\mathrm{Cu}_{2} \mathrm{O}$ and $\mathrm{CuO}$ (Figure 3E,F) particles also had significant antibacterial activity, they had lower growth inhibition levels against E. coli than those of $\mathrm{ZnO}-(2)$ particles. Antibacterial activity against $E$. coli was affected by physicochemical characteristics of $\mathrm{MO}$ particles. In $\mathrm{ZnO}$ particles, $\mathrm{ZnO}-(2)$ particles had enhanced antibacterial activity compared with $\mathrm{ZnO}-(1)$ particles depending on particle size [ $\mathrm{ZnO}-(1)>\mathrm{ZnO}-(2)]$. In addition to particle size effect, antibacterial activity of $\mathrm{MO}$ particles was shown in order of $\mathrm{ZnO}>\mathrm{MgO}>\mathrm{Cu}_{2} \mathrm{O}=\mathrm{CuO}$ particles based on the variety of all particles.
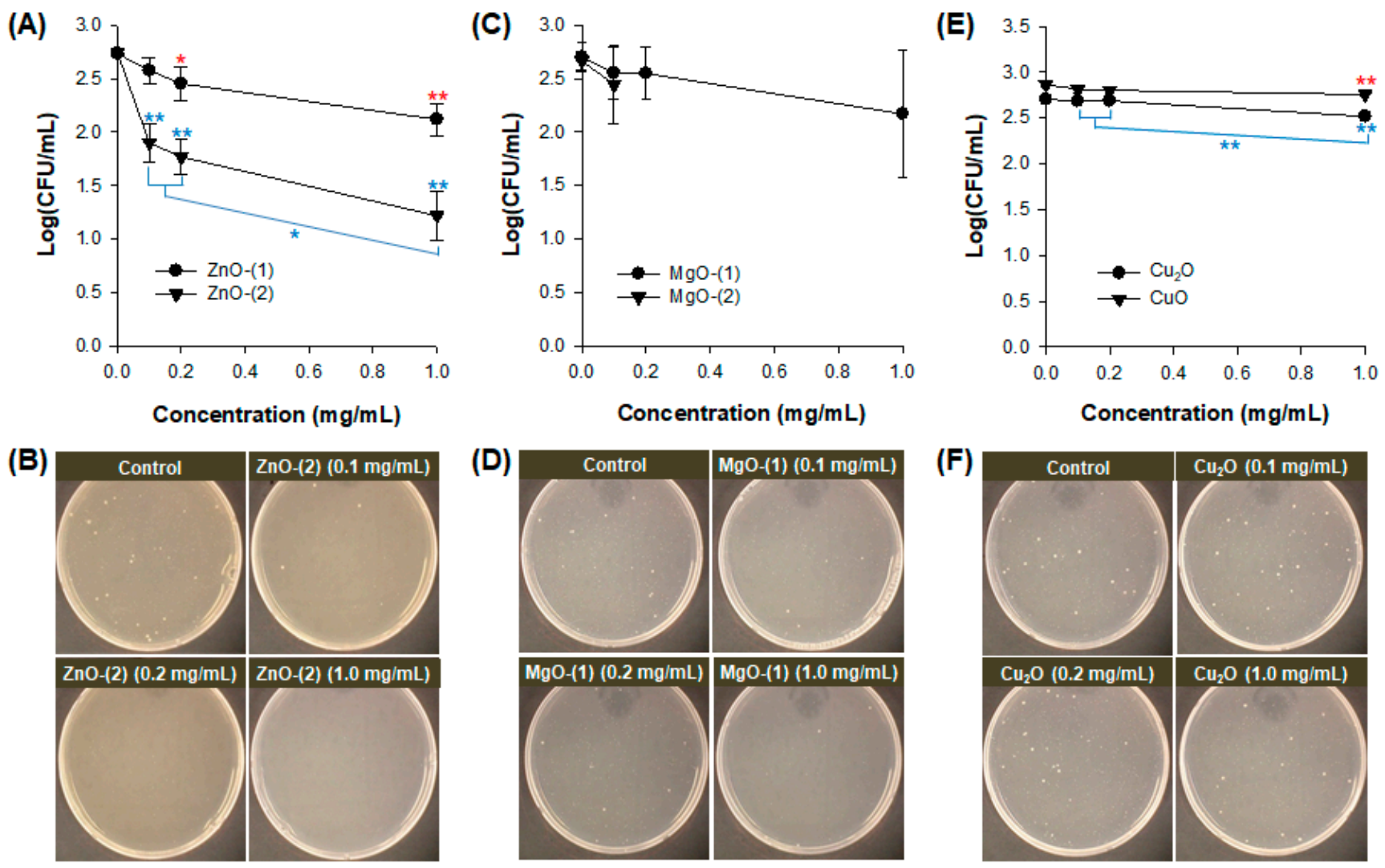

Figure 3. Antimicrobial effect of metal oxide $(\mathrm{MO})$ particles against Escherichia coli: plots of concentration $(\mathrm{mg} / \mathrm{mL})$ versus $\log (\mathrm{CFU} / \mathrm{mL})$ and representative plate images of (A,B) $\mathrm{ZnO}-(1)$, and $\mathrm{ZnO}-(2) ;(\mathbf{C}, \mathbf{D}) \mathrm{MgO}-(1)$, and $\mathrm{MgO}-(2) ;(\mathbf{E}, \mathbf{F}) \mathbf{C u} 2 \mathrm{O}$, and $\mathrm{CuO} .{ }^{*}, p<0.05 ;{ }^{* *}, p<0.01$.

\subsubsection{Inactivation Activity against Phage}

Viral inactivation activity of $\mathrm{MO}$ particles was determined against phage in the dark (Figure 4). All particles of $\mathrm{ZnO}$ (Figure 4A,B), $\mathrm{MgO}$ (Figure 4C,D), $\mathrm{Cu}_{2} \mathrm{O}$ and $\mathrm{CuO}$ (Figure $4 \mathrm{E}, \mathrm{F}$ ) at $0.1-1.0 \mathrm{mg} / \mathrm{mL}$ showed no inactivation activity against phage after 30-min incubation. While virus plaques were inspected on plates as blue dots, no viral inactivation was confirmed in the representative plate images of $\mathrm{ZnO}-(2)$ particles (Figure $4 \mathrm{~B}$ ) along with all the other particles (Figure 4D,F) despite the enhanced antibacterial activity. 

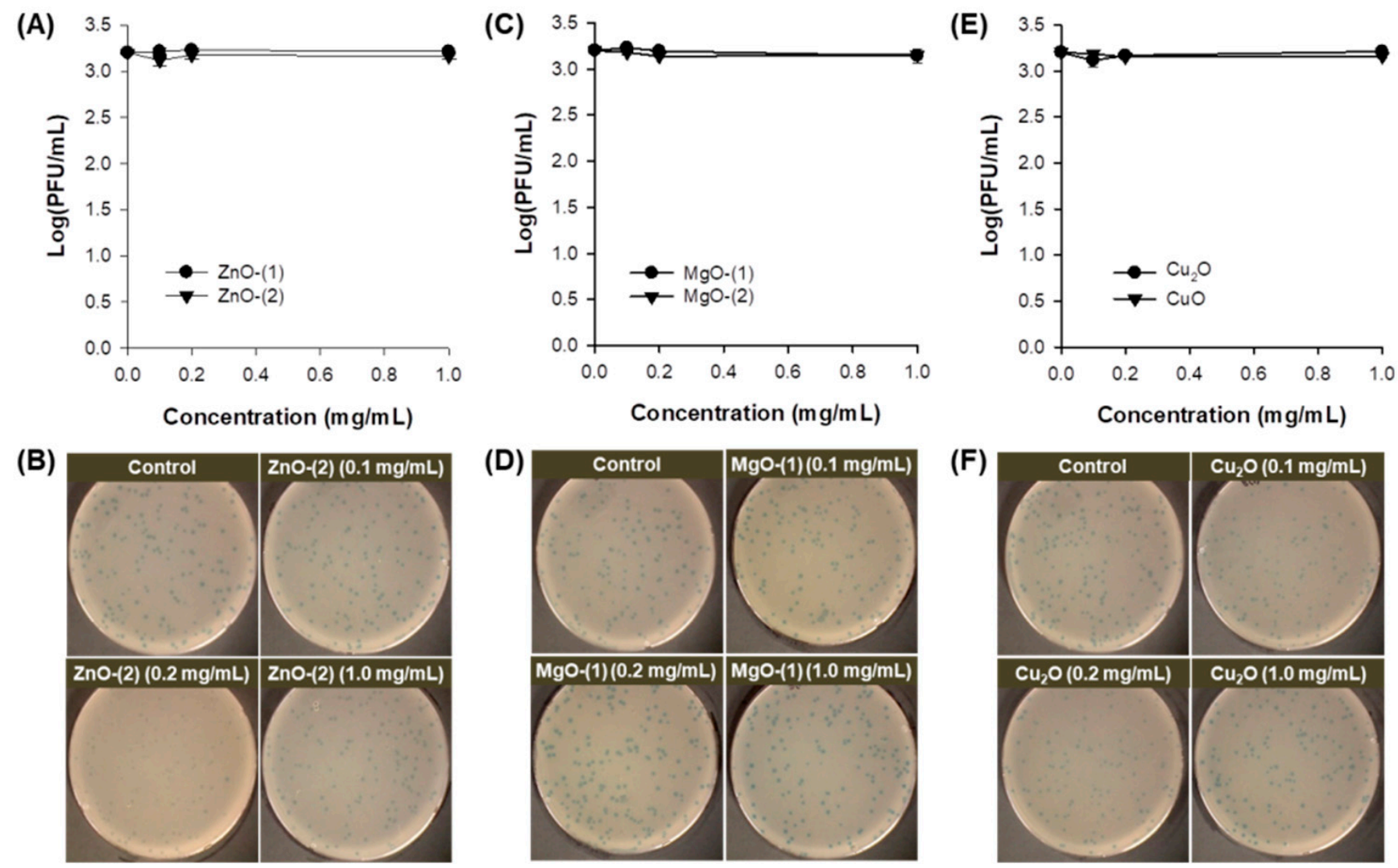

Figure 4. Antimicrobial effect of metal oxide (MO) particles against phage: plots of concentration $(\mathrm{mg} / \mathrm{mL}) \mathrm{versus}$ $\log (\mathrm{PFU} / \mathrm{mL})$ and the representative plate images of (A,B) $\mathrm{ZnO}-(1)$, and $\mathrm{ZnO}-(2) ;(\mathbf{C}, \mathbf{D}) \mathrm{MgO}-(1)$, and $\mathrm{MgO}-(2)$; and (E,F) $\mathrm{Cu}_{2} \mathrm{O}$, and $\mathrm{CuO}$.

\subsection{Dual UV-MO Particle Hybrid-Based Antimicrobial Activity}

\subsubsection{Antibacterial Activity against E. coli under Dual UV Irradiation}

Combination of dual UV and MO particles showed enhanced antibacterial efficacy against $E$. coli compared to MO particles alone (Figure 5). MO particles were used at 0.1 and $1.0 \mathrm{mg} / \mathrm{mL}$. In dual UV irradiation for 10 and $30 \mathrm{~s}$, coated or uncoated areas of UV lamp were applied as controllable factors for high or low UV-C intensity. Enhanced antibacterial inhibition against $E$. coli were displayed at higher concentration of $\mathrm{MO}$ particles (except $\mathrm{ZnO}-(2)$ and $\mathrm{CuO}$ ), higher UV-C intensity, and longer UV exposure time. In $\mathrm{MO}$ particles, antibacterial activity under dual UV irradiation was the highest in $\mathrm{ZnO}-(1)$ particles and the lowest in $\mathrm{MgO}-(2)$ particles $\left(\mathrm{ZnO}-(1)>\mathrm{MgO}-(1)>\mathrm{ZnO}-(2)>\mathrm{CuO}>\mathrm{Cu}_{2} \mathrm{O}>\mathrm{MgO}-(2)\right)$. Although $\mathrm{ZnO}-(1)$ particles were larger than $\mathrm{ZnO}-(2)$ particles, $\mathrm{ZnO}-(1)$ particles had superior antibacterial activity against $E$. coli than $\mathrm{ZnO}$-(2) particles under dual UV irradiation. These results are contrary to those of antibacterial test without UV irradiation. It suggested that multiscale MO particles can enhance antibacterial activity as photocatalysts for ROS generation under dual UV irradiation. 

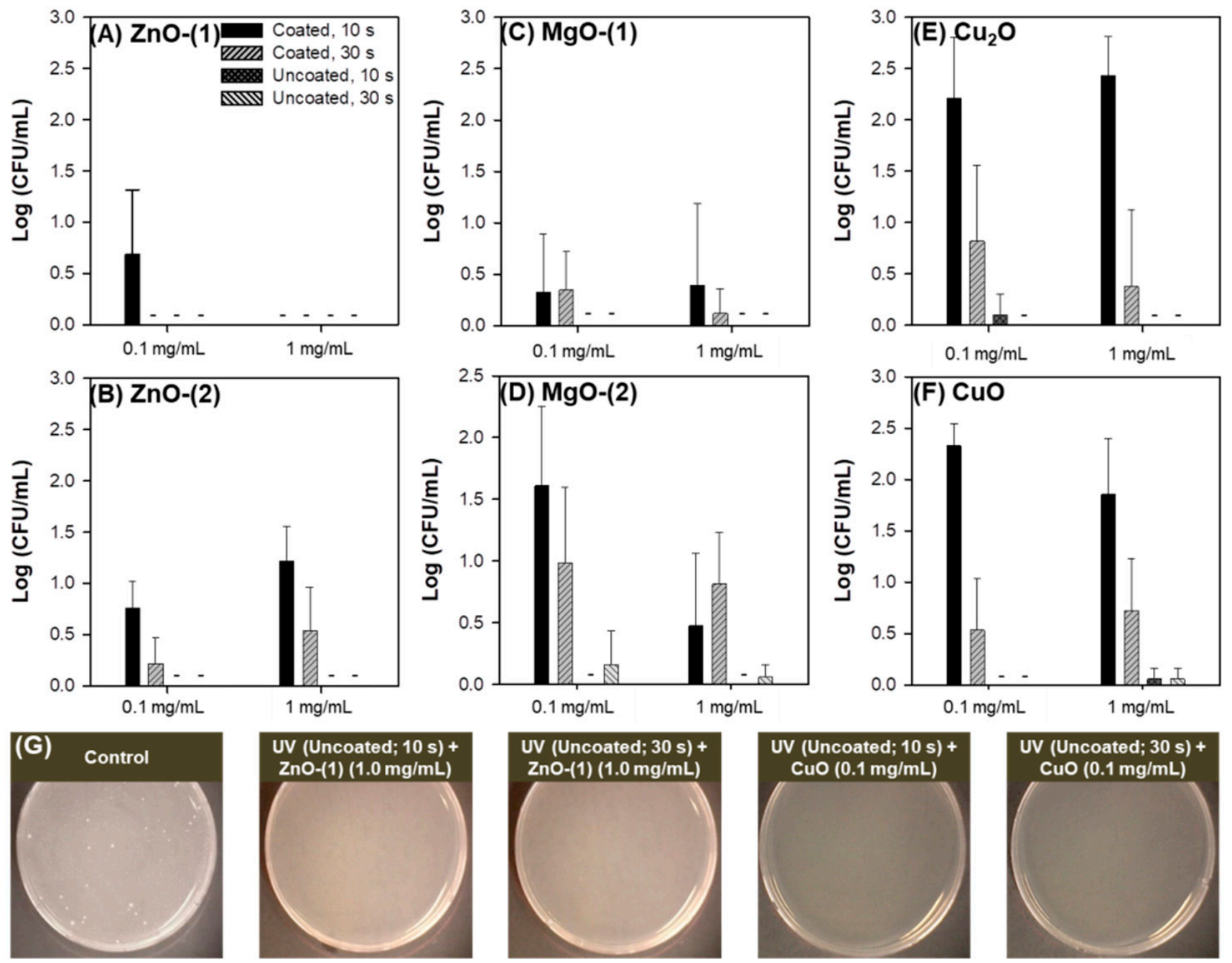

Figure 5. Antimicrobial effect of dual ultraviolet (UV)-metal oxide (MO) particle hybrids against E. coli: (A) ZnO-(1), (B) $\mathrm{ZnO}-(2),(\mathbf{C}) \mathrm{MgO}-(1),(\mathbf{D}) \mathrm{MgO}-(2),(\mathbf{E}) \mathrm{Cu}_{2} \mathrm{O}$, and (F) $\mathrm{CuO} ;(\mathbf{G})$ representative plate images of colonies. -, not detected.

\subsubsection{Inactivation Activity against Phage under Dual UV Irradiation}

Antimicrobial effect of dual UV-MO particle hybrids on phage was also investigated (Figure 6). Under dual UV irradiation, MO particles showed viral inactivation activity against phage. $\mathrm{ZnO}-(1), \mathrm{ZnO}-(2), \mathrm{MgO}-(2), \mathrm{Cu}_{2} \mathrm{O}$ and $\mathrm{CuO}$ particles had viral inactivation activity even at lower concentration $(0.1 \mathrm{mg} / \mathrm{mL})$ for 30 -s dual UV irradiation using lamp at uncoated side, except for $\mathrm{MgO}-(1)$ particles. Specifically, antimicrobial activity of $\mathrm{CuO}$ and $\mathrm{ZnO}-(1)$ particles in multiscale $\mathrm{MO}$ particles was enhanced under dual UV irradiation from uncoated area of UV lamp due to the high UV-C intensity based on combination effect (Figure $6 \mathrm{G})$. MO particles at low concentration $(0.1 \mathrm{mg} / \mathrm{mL})$ were more efficient than those at high concentration $(1.0 \mathrm{mg} / \mathrm{mL})$ except MgO-(1) particles. Viral inactivation potential was the highest in $\mathrm{CuO}$ particles and the lowest in $\mathrm{MgO}-(1)$ particles among $\mathrm{MO}$ particles $\left[\mathrm{CuO}>\mathrm{Cu}_{2} \mathrm{O}>\mathrm{ZnO}-(1)=\mathrm{MgO}-(2)>\mathrm{ZnO}-(2)>\mathrm{MgO}-(1)\right]$ under dual UV irradiation. Although $\mathrm{MO}$ particles themselves had antibacterial activity in a dose-dependent manner, UV irradiation platforms along with MO particles were necessary to inactivate viruses effectively. 

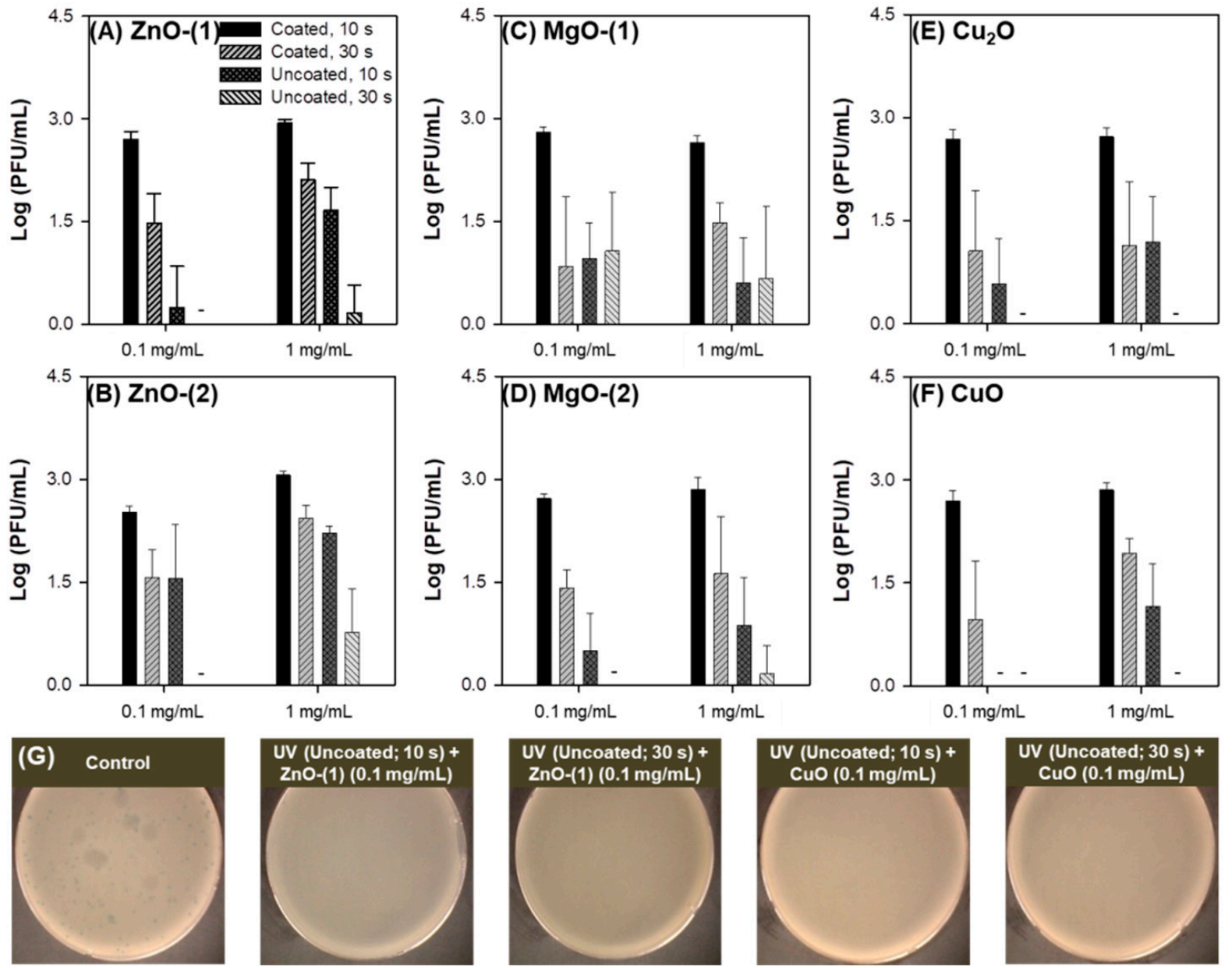

Figure 6. Antimicrobial effect of dual ultraviolet (UV)-metal oxide (MO) particle hybrids against phage: (A) ZnO-(1), (B) $\mathrm{ZnO}-(2),(\mathbf{C}) \mathrm{MgO}-(1),(\mathbf{D}) \mathrm{MgO}-(2),(\mathbf{E}) \mathrm{Cu}_{2} \mathrm{O}$, and (F) $\mathrm{CuO}$; (G) representative plate images of phage plaques. -, not detected.

\section{Discussion}

Antibiotic properties of MO particles have been mainly affected by physicochemical characteristics including morphology and particle size [1,21]. MO NPs are generally described as nano-antibiotics to combat multidrug resistance in pathogenic microorganisms [22], where antimicrobial activity is superior than that of MO MPs in most reports of antimicrobial activity tests. However, in some cases, MO MPs also showed strong antimicrobial activity based on their structural properties or combinations with other materials such as polymers and metallic compounds $[23,24]$. In the present study, antimicrobial activity of multiscale MO particles against E. coli and phage was investigated with or without dual UV irradiation to clarify the interactions between physicochemical characteristics, specifically particle size distribution, and biological responses in microorganisms for enhanced performance. Particle size distribution of MO particles in a multiscale mixture of $\mathrm{NPs}$ and MPs at nano-to-microscale size range (ZnO-(1) and $\mathrm{CuO}$ particles) was explored as a critical factor for their antimicrobial actions under dual UV irradiation.

First of all, morphology of MO particles affected antimicrobial activity via the interactions of the particles with microorganisms under dual UV irradiation [24]. MO particles showed needles or rods (Figure 1A,B), spheres or cubes (Figure 1C,D), and curved or angular shapes (Figure 1E,F). Compared to spherical NPs, MO NPs with high aspect ratios can be predicted as highly toxic materials with exposure risks for enhanced antimicrobial activity against bacteria and viruses $[25,26]$. However, irregular-shaped NPs of high aspect 
ratios (disc, rod, and needle) at 18.59-22.20 nm showed more cytotoxicity in MG-63 cells at $0.5 \mathrm{mg} / \mathrm{mL}$ than the spherical NPs after $24 \mathrm{~h}$ of incubation under the same conditions as those for antimicrobial activity enhancement [27].

Predicting antimicrobial effect of MO NPs against pathogenic microorganisms, MO NPs with smaller size (<100 nm) significantly offer higher antibiotic potentials, despite the association with morphology [28]. However, regarding aggregate generation of MO NPs in the hydrodynamic environment (Figure S1), multiscale MO particles can mimic nanoor microstructured aggregate generation containing nano-to-microscale particles (Table S1) and possibly induce multiple scattering for enhanced mass transfer and exchange rate under UV and visible light irradiation [29,30]. In photocatalysis for enhanced ROS generation, to induce oxidative stress against microorganisms, multiple scattering phenomena of multiscale MO particles increase photon utilization efficiency to improve an expected photo-redox performance.

Chemical composition and purity of MO particles also provide fundamental information on their antibiotic potential against pathogenic microorganisms [31]. They have a high priority even at macroscale particles in the physicochemical characteristics affected to biological responses, recommended by Organization for Economic Co-operation and Development (OECD) [21]. MO particles had atomic compositions as pure chemical formulae (Table 1), which were determined using EDS spectra (Figure S2). Specifically, binding energy levels of $\mathrm{ZnO}$-(1) particles for investigating chemical states of surface defects were confirmed in XPS spectrum based on elemental surface composition suggesting the environmental interaction of particles influenced by air and carbon taping (Figure S3).

Crystallinity is one of key physicochemical characteristics to influence photocatalytic performance under UV and visible light irradiation based on band gap energy [32]. Biological interactions of $\mathrm{MO}$ particles as photocatalysts can be predicted by band gap energy that ranged from -4.12 to $-4.84 \mathrm{eV}$ of cellular redox potential, suggesting electron transfer between particle surfaces and cellular redox couples for oxidative stress [33]. MO particles of $\mathrm{ZnO}, \mathrm{MgO}, \mathrm{Cu}_{2} \mathrm{O}$, and $\mathrm{CuO}$ had highly crystalline structures as pure materials of hexagonal wurtzite crystals, cubic lattices, cubic polycrystalline, and monoclinic phased crystals, respectively (Figure 2). Connecting to biological responses, crystal structures of MO particles can also provide antimicrobial potentials against pathogenic microorganisms.

In surface characteristics, porosity is essential to investigate the adsorption potential of MO particles in antimicrobial actions [34]. Large mesopores (10-50 nm) in MO particles induce fast biochemical adsorption on the particle surfaces, which has contributed to enhanced reaction rate, compared to small mesopores $(2-10 \mathrm{~nm})$. Depending on $\mathrm{MO}$ particle types, pore size strongly affected antimicrobial activity against microorganisms (Table 2).

For antimicrobial activity test, E. coli and phage have been extensively used as model microorganisms of bacteria and viruses [35,36]. E. coli is one of the most rapidly growing bacteria to easily quantify the colonies via UV-visible scanning for turbidity measurement and colony counting on agar plates $[37,38]$. It is a representative screening system for antibiotic materials in terms of metabolic process interruption leading to cell death or cell stasis. Expressing pck, acs, and atpAGD in ATP-consuming cycles of E. coli, cells are genetically sensitized to exogenous oxidative stress for bactericidal action. In addition, translation inhibition in E. coli induces bacteriostatic condition of decreasing cell respiration, which is similar to genetic cytochrome oxidase disruption in metabolic processes. Next, phage is a strong filamentous bacterial virus for antimicrobial activity test, which can induce multidrug resistance as a genetic reservoir [39]. However, they were recently studied to develop antimicrobial agents based on bioengineered phage-based bacterial infection combating multidrug resistance in bacteria [40]. Phage is also useful to quantify the plaque as an experimental system after bacterial infection. Therefore, E. coli and phage can be appropriate models for antibiotic screening and mechanistic study on how MO particles inhibit the bacterial and viral growth. 
MO particles themselves have showed antimicrobial activity against microorganisms [22,35]. In the present study, spherical or cuboidal $\mathrm{MgO}$ particles presented lower antimicrobial activity against $E$. coli than $\mathrm{ZnO}, \mathrm{Cu}_{2} \mathrm{O}$, and $\mathrm{CuO}$ particles (Figure 3). Comparing with previous reports of MO NPs, ZnO NPs had $0.1-57.9 \%$ survival rates against E. coli $\left(10^{6}\right)$, conversely at $0.01-1 \mathrm{mg} / \mathrm{mL}$ [41]. MgO NPs at $100 \mathrm{mg} / \mathrm{mL}$ were bactericidal against $E$. coli after 1-h incubation despite no antibacterial performance against $S$. aureus within 3-h incubation [42]. In addition, $\mathrm{CuO}$ NPs at 25 and $50 \mu \mathrm{g} / \mathrm{mL}$ showed $87 \%$ and $92 \%$ growth inhibition rates against $E$. coli after 16-h incubation although the growth inhibition rates were not significantly reduced at approximately $2.11 \%$ for both concentrations after 1-h incubation [43].

All MO particles themselves had no inactivation activity against phage (Figure 4) because the phage is resistant to environmental stresses such as heat and $\mathrm{pH}$ [44]. However, an immunoprotective function of $\mathrm{ZnO}$ NPs as virostatic agents has been reported against genital Herpes viruses preventing the viral entry to cells and subsequent infection via generating complexes by charge-charge interaction $[45,46] . \mathrm{Cu}_{2} \mathrm{O}$ NPs also have an in vitro antiviral activity against Hepatitis $C$ inhibiting the viral entry and further infection to cells, with hindrance to viral replication $[45,47]$.

At this point, the hybridization of MO particles with dual UV was tested to investigate the effects of particle size distribution of MO particles and combination with dual UV for enhanced photocatalytic antimicrobial performance against bacteria as well as viruses. The antimicrobial activity of MO particles at multiscale size levels and dual UV of UV-A and UV-C irradiating differential UV-C intensity depending on irradiation time, were analyzed against $E$. coli and phage. In $\mathrm{MO}$ particles, $\mathrm{ZnO}-(1)$ and $\mathrm{CuO}$ particles had multiscale particle size distributions although $\mathrm{ZnO}-(2)$ and $\mathrm{MgO}-(1)$ particles showed nanoscale size levels, and $\mathrm{MgO}-(2)$ and $\mathrm{Cu}_{2} \mathrm{O}$ particles displayed microscale size levels. Multiscale $\mathrm{ZnO}$ and $\mathrm{CuO}$ particles showed superior antimicrobial activity against E. coli (Figure 5) and phage (Figure 6) compared with other scale particles, due to large surface area and multiple scattering under dual UV irradiation [5,6,30]. The large surface area of multiscale $\mathrm{ZnO}$ ( $\mathrm{ZnO}-(1)>\mathrm{ZnO}-(2)$ by 4.0 -fold) and $\mathrm{CuO}\left(\mathrm{CuO}>\mathrm{Cu}_{2} \mathrm{O}\right.$ by 5.6 -fold) particles induced charge-charge interaction to cause membrane damage of pathogenic microorganisms for enhanced antimicrobial performance $[48,49]$. The microstructured particle aggregates with polydispersity also showed multiple scattering phenomena improving particular interactions via mass transfer and exchange in multilevel porosity, including the biomodality of macropores and mesopores for enhanced photocatalysis promoting antimicrobial action $[50,51]$. Enhanced photocatalytic antimicrobial actions of multiscale MO particles could be explained by multiple scattering of nano- or microstructured MO particle clusters in a hydrodynamic environment connecting to dual UV irradiation. These results were also superior to previously reported data for MO NPs and dual UV hybrids [11].

The antimicrobial mechanisms of multiscale MO particles can be explained by the release of metal ions, particle shape dependency, particle adsorption to the biomembrane of microorganisms, and ROS generation under dual UV irradiation [2,4]. High metal ion release, high aspect ratio in morphology, large surface area, and enhanced photocatalytic activities are critical characteristics of multiscale $\mathrm{MO}$ particles for enhanced antimicrobial performance. Specifically, biomembrane adsorption and ROS generation are primarily considered as expected antimicrobial mechanisms that cause biomembrane damage and DNA breaks against microorganisms (Figure 7). The adsorption potential was induced by the physicochemical characteristics of the MO particles, including hydrophobicity, porosity, and dispersibility in an aqueous environment. In ROS generation, multiscale MO particles generate particle aggregates mimicking nano-to-microscale architecture for enhanced photocatalytic performance even at lower concentrations via multiple scattering [52]. In addition, emulating surface defects of multiscale MO particles could improve the antimicrobial activity in a hydrodynamic environment due to their enhanced ROS production from oxygen vacancies [53-55]. In particular, the structures of MO NPs or MPs affected the surface oxygen vacancies, resulting in enhanced ROS generation for antimicrobial perfor- 
mance based on electron-hole pair generation [55-57]. However, in the case of $\mathrm{CuO}$ and $\mathrm{Cu}_{2} \mathrm{O}$ particles, $\mathrm{CuO}$ particles reduce the superoxide radicals to produce $\mathrm{Cu}^{+}$, and $\mathrm{Cu}_{2} \mathrm{O}$ particles do not generate any superoxide radicals for sustained oxidative stress during redox cycling [58]. In these phenomena, although $\mathrm{CuO}-\mathrm{Cu}_{2} \mathrm{O}$ particles generated no superoxide species, superoxide anion radical $\left(\mathrm{O}_{2} \cdot{ }^{-}\right)$or hydroxyl radical $(\mathrm{OH} \cdot)$ was produced through the Fenton reaction. Chelation complex formation or metabolic enzyme damage was caused in microorganisms by ROS from $\mathrm{Cu}_{2} \mathrm{O}$ and $\mathrm{CuO}$ particles, respectively. Therefore, multiscale $\mathrm{MO}$ particles can be used as alternatives to antibiotic agents for enhanced performance based on differential antimicrobial pathways to overcome drug resistance.

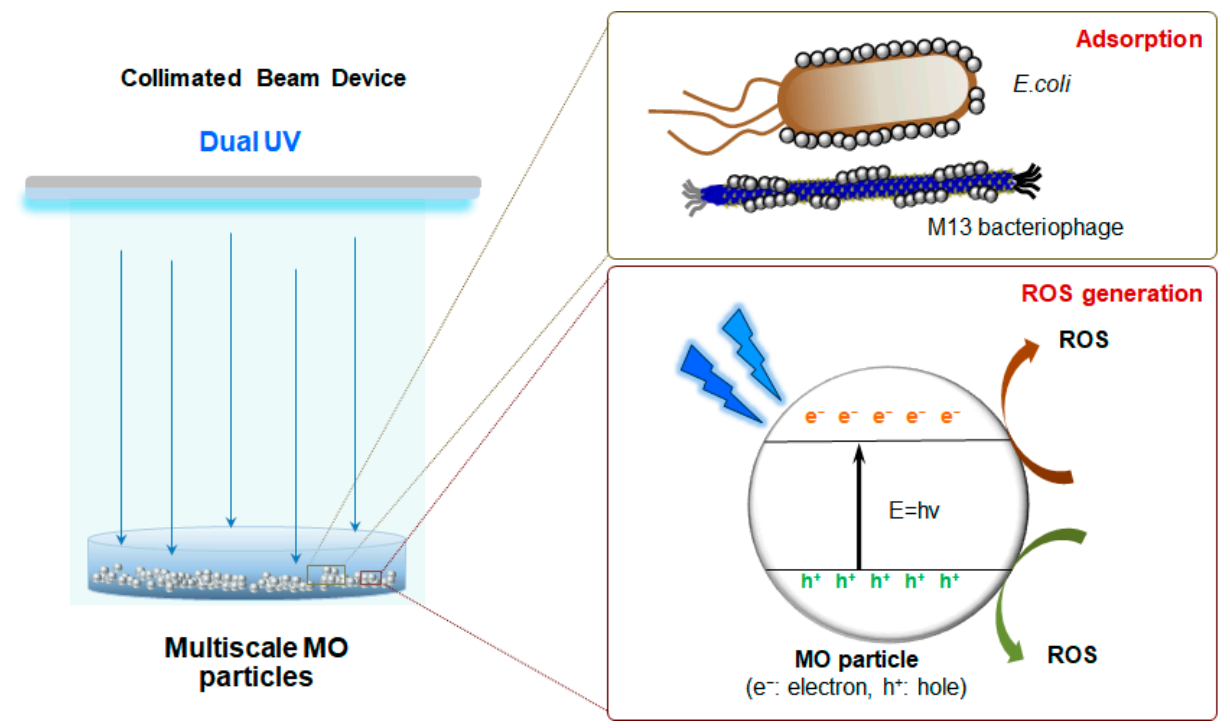

Figure 7. Schematic diagram of main antimicrobial mechanisms of a dual ultraviolet (UV)-multiscale metal oxide $(\mathrm{MO})$ particle system for enhanced antimicrobial action. In water, multiscale $\mathrm{MO}$ particles were adsorptive to $E$. coli and phage resulting in biomembrane rupture and cell death. They generated reactive oxygen species (ROS) under dual UV irradiation promoting an electron from valence band to conduction band by a band gap energy.

\section{Conclusions}

Multiscale MO particles had nano- to microscale sizes as mixtures of NPs and MPs, which were identified as pure materials, confirmed by atomic compositions and crystallinity, and further evaluated by surface characteristics. In $\mathrm{ZnO}, \mathrm{MgO}, \mathrm{Cu}_{2} \mathrm{O}$, and $\mathrm{CuO}$ particles, multiscale $\mathrm{ZnO}$ and $\mathrm{CuO}$ particles showed enhanced antimicrobial activity against $E$. coli as well as phage under dual UV irradiation, based on their physicochemical characteristics. In particular, surface adsorption to biomembrane and ROS generation under dual UV irradiation can be the main mechanisms of antimicrobial action due to large surface area with enhanced mass transfer via multiple scattering. From the results, multiscale MO particles will be promising antibiotic agents to apply in environment, industry, and clinics for near future. It can also be extended to customized multiple combination mixtures of multiscale MO particles as photocatalysts in dual UV hybrid systems for enhanced performance overcoming antibiotic resistance.

Supplementary Materials: The following are available online at https: / www.mdpi.com/1999-4 923/13/2/222/s1, Figure S1: Size distributions of MO particles in the hydrodynamic environment, Figure S2: EDS spectra of MO particles, Figure S3: XPS spectrum of multiscale ZnO-(1) particles, Table S1: Particle size distributions of MO particles in the hydrodynamic environment. 
Author Contributions: Conceptualization, S.-E.J. and H.-E.J.; methodology, S.-E.J. and H.-E.J.; software, S.-E.J. and H.-E.J.; formal analysis, S.-E.J. and H.-E.J.; investigation, S.-E.J. and H.-E.J.; writingoriginal draft preparation, S.-E.J.; writing—review and editing, S.-E.J. and H.-E.J.; visualization, S.-E.J. and H.-E.J.; supervision, S.-E.J. and H.-E.J.; project administration, S.-E.J.; funding acquisition, S.-E.J. All authors have read and agreed to the published version of the manuscript.

Funding: This work was supported by the Korea Ministry of Environment (MOE) as “The advancement of scientific research and technological development in environmental science program (2016000140006)"

Institutional Review Board Statement: Not applicable.

Informed Consent Statement: Not applicable.

Data Availability Statement: The data presented in this study are available in article or supplementary material.

Acknowledgments: We thank Woochul Hwang in ECOSET Co., Ltd. (Ansan, Korea) for providing a dual-UV lamp operating system. We also thank Hyo Jung Lee for assisting with technical experiments.

Conflicts of Interest: The authors declare no conflict of interest.

\section{References}

1. Gold, K.; Slay, B.; Knackstedt, M.; Gaharwar, A.K. Antimicrobial Activity of Metal and Metal-Oxide Based Nanoparticles. Adv. Ther. 2018, 1, 1700033. [CrossRef]

2. Kotov, N.A.; Vanepps, J.S. Antibacterial Metal Oxide Nanoparticles: Challenges in Interpreting the Literature. Curr. Pharm. Des. 2018, 24, 896-903. [CrossRef]

3. Azam, A.; Ahmed, A.S.; Oves, M.; Khan, M.S.; Habib, S.S.; Memic, A. Antimicrobial activity of metal oxide nanoparticles against Gram-positive and Gram-negative bacteria: A comparative study. Int. J. Nanomed. 2012, 7, 6003-6009. [CrossRef]

4. Vanepps, J.S.; Turali-Emre, E.S.; Bahng, J.H.; Kotov, N.A.; Vanepps, J.S. Unexpected insights into antibacterial activity of zinc oxide nanoparticles against methicillin resistant Staphylococcus aureus (MRSA). Nanoscale 2018, 10, 4927-4939. [CrossRef]

5. Hwang, G.; Paula, A.J.; Hunter, E.E.; Liu, Y.; Babeer, A.; Karabucak, B.; Stebe, K.; Kumar, V.; Steager, E.; Koo, H. Catalytic antimicrobial robots for biofilm eradication. Sci. Robot. 2019, 4, eaaw2388. [CrossRef] [PubMed]

6. Manke, A.; Wang, L.; Rojanasakul, Y. Mechanisms of Nanoparticle-Induced Oxidative Stress and Toxicity. BioMed Res. Int. 2013, 2013, 942916. [CrossRef]

7. Sánchez-López, E.; Gomes, D.; Esteruelas, G.; Bonilla, L.; Lopez-Machado, A.L.; Galindo, R.; Cano, A.; Espina, M.; Ettcheto, M.; Camins, A.; et al. Metal-Based Nanoparticles as Antimicrobial Agents: An Overview. Nanomatererials 2020, 10, 292. [CrossRef]

8. Jolivet, J.-P.; Cassaignon, S.; Chanéac, C.; Chiche, D.; Durupthy, O.; Portehault, D. Design of metal oxide nanoparticles: Control of size, shape, crystalline structure and functionalization by aqueous chemistry. Comptes Rendus Chim. 2010, 13, 40-51. [CrossRef]

9. Yamamoto, O. Influence of particle size on the antibacterial activity of zinc oxide. Int. J. Inorg. Mater. 2001, 3, 643-646. [CrossRef]

10. Rahmati, M.; Silva, E.A.; Reseland, J.E.; Heyward, C.A.; Haugen, H.J. Biological responses to physicochemical properties of biomaterial surface. Chem. Soc. Rev. 2020, 49, 5178-5224. [CrossRef]

11. Jin, S.-E.; Hwang, W.; Lee, H.J.; Jin, H.-E. Dual UV irradiation-based metal oxide nanoparticles for enhanced antimicrobial activity in Escherichia coli and M13 bacteriophage. Int. J. Nanomed. 2017, 12, 8057-8070. [CrossRef]

12. Malka, E.; Perelshtein, I.; Lipovsky, A.; Shalom, Y.; Naparstek, L.; Perkas, N.; Patick, T.; Lubart, R.; Nitzan, Y.; Banin, E.; et al. Eradication of Multi-Drug Resistant Bacteria by a Novel Zn-doped CuO Nanocomposite. Small 2013, 9, 4069-4076. [CrossRef]

13. Jin, S.-E.; Jin, H.-E. Synthesis, Characterization, and Three-Dimensional Structure Generation of Zinc Oxide-Based Nanomedicine for Biomedical Applications. Pharmaceutics 2019, 11, 575. [CrossRef]

14. Jin, S.-E.; Jin, H.-E. Antimicrobial Activity of Zinc Oxide Nano/Microparticles and Their Combinations against Pathogenic Microorganisms for Biomedical Applications: From Physicochemical Characteristics to Pharmacological Aspects. Nanomatererials 2021, 11, 263. [CrossRef]

15. Argyraki, A.; Markvart, M.; Stavnsbjerg, C.; Kragh, K.N.; Ou, Y.; Bjørndal, L.; Bjarnsholt, T.; Petersen, P.M. UV light assisted antibiotics for eradication of in vitro biofilms. Sci. Rep. 2018, 8, 16360. [CrossRef]

16. Umar, M.; Roddick, F.; Fan, L. Moving from the traditional paradigm of pathogen inactivation to controlling antibiotic resistance in water-Role of ultraviolet irradiation. Sci. Total. Environ. 2019, 662, 923-939. [CrossRef]

17. Visnapuu, M.; Rosenberg, M.; Truska, E.; Nõmmiste, E.; Šutka, A.; Kahru, A.; Rähn, M.; Vija, H.; Orupõld, K.; Kisand, V.; et al. UVA-induced antimicrobial activity of ZnO/Ag nanocomposite covered surfaces. Colloids Surf. B Biointerfaces 2018, 169, 222-232. [CrossRef] [PubMed]

18. Dai, T.; Vrahas, M.S.; Murray, C.K.; Hamblin, M.R. Ultraviolet C irradiation: An alternative antimicrobial approach to localized infections? Expert Rev. Anti-Infect. Ther. 2012, 10, 185-195. [CrossRef] [PubMed]

19. Shaikh, S.; Nazam, N.; Rizvi, S.M.D.; Ahmad, K.; Baig, M.H.; Lee, E.J.; Choi, I. Mechanistic Insights into the Antimicrobial Actions of Metallic Nanoparticles and Their Implications for Multidrug Resistance. Int. J. Mol. Sci. 2019, 20, 2468. [CrossRef] 
20. Wang, L.; Hu, C.; Shao, L. The antimicrobial activity of nanoparticles: Present situation and prospects for the future. Int. J. Nanomed. 2017, 12, 1227-1249. [CrossRef] [PubMed]

21. Rasmussen, K.; Rauscher, H.; Mech, A.; Sintes, J.R.; Gilliland, D.; González, M.; Kearns, P.; Moss, K.; Visser, M.; Groenewold, M.; et al. Physico-chemical properties of manufactured nanomaterials-Characterisation and relevant methods. An outlook based on the OECD Testing Programme. Regul. Toxicol. Pharmacol. 2018, 92, 8-28. [CrossRef] [PubMed]

22. Makabenta, J.M.V.; Nabawy, A.; Li, C.-H.; Schmidt-Malan, S.; Patel, R.; Rotello, V. Nanomaterial-based therapeutics for antibioticresistant bacterial infections. Microbiology 2021, 19, 23-36. [CrossRef] [PubMed]

23. Mala, N.; Ravichandran, K.; Pandiarajan, S.; Srinivasan, N.; Ravikumar, B.; Pushpa, K.C.S.; Swaminathan, K.; Arun, T. Formation of hexagonal plate shaped $\mathrm{ZnO}$ microparticles-A study on antibacterial and magnetic properties. Ceram. Int. 2016, 42, 7336-7346. [CrossRef]

24. Sophee, S.S.; Prasad, R.G.S.V.; Srinivas, J.V.; Aparna, R.S.L.; Phani, A.R. Antibacterial Activity of TiO2 and ZnO Microparticles Combination on Water Polluting Bacteria. J. Green Sci. Technol. 2013, 1, 20-26. [CrossRef]

25. Brayner, R. The toxicological impact of nanoparticles. Nano Today 2008, 3, 48-55. [CrossRef]

26. Djurišić, A.B.; Leung, Y.H.; Ng, A.M.C.; Xu, X.Y.; Lee, P.K.H.; Degger, N.; Wu, R.S.S. Toxicity of Metal Oxide Nanoparticles: Mechanisms, Characterization, and Avoiding Experimental Artefacts. Small 2015, 11, 26-44. [CrossRef]

27. Vasile, O.R.; Serdaru, I.; Andronescu, E.; Truşcă, R.; Surdu, V.A.; Oprea, O.; Ilie, A.; Vasile, B. Ştefan Influence of the size and the morphology of ZnO nanoparticles on cell viability. Comptes Rendus Chim. 2015, 18, 1335-1343. [CrossRef]

28. Dizaj, S.M.; Lotfipour, F.; Barzegar-Jalali, M.; Zarrintan, M.H.; Adibkia, K. Antimicrobial activity of the metals and metal oxide nanoparticles. Mater. Sci. Eng. C 2014, 44, 278-284. [CrossRef]

29. Sedlak, J.; Kuřitka, I.; Masař, M.; Machovský, M.; Urbánek, P.; Bažant, P.; Janota, P.; Dvorackova, M. Contributions of morphological and structural parameters at different hierarchical morphology levels to photocatalytic activity of mesoporous nanostructured ZnO. Appl. Surf. Sci. 2020, 513, 145773. [CrossRef]

30. Zhang, N.; Han, C.; Fu, X.; Xu, Y.-J. Function-Oriented Engineering of Metal-Based Nanohybrids for Photoredox Catalysis: Exerting Plasmonic Effect and Beyond. Chem 2018, 4, 1832-1861. [CrossRef]

31. da Silva, L.B.; Abuçafy, M.P.; Berbel, M.E.; Oshiro Junior, J.A.; Chiari-Andréo, B.G.; Pietro, R.C.R.; Chiavacci, L.A. Relationship between structure and antimicrobial activity of zinc oxide nanoparticles: An overview. Int. J. Nanomed. 2019, 14, 9395-9410. [CrossRef]

32. Nguyen, T.-D.; Dinh, C.-T.; Doa, T.-O. A general procedure to synthesize highly crystalline metal oxide and mixed oxide nanocrystals in aqueous medium and photocatalytic activity of metal/oxide nanohybrids. Nanoscale 2011, 3, 1861-1873. [CrossRef]

33. Zhang, H.; Ji, Z.; Xia, T.; Meng, H.; Low-Kam, C.; Liu, R.; Pokhrel, S.; Lin, S.; Wang, X.; Liao, Y.-P.; et al. Use of Metal Oxide Nanoparticle Band Gap To Develop a Predictive Paradigm for Oxidative Stress and Acute Pulmonary Inflammation. ACS Nano 2012, 6, 4349-4368. [CrossRef] [PubMed]

34. Suresh, K.P.; Korving, L.; Keesman, K.J.; van Loosdrecht, M.C.M.; Witkamp, G.-J. Effect of pore size distribution and particle size of porous metal oxides on phosphate adsorption capacity and kinetics. Chem. Eng. Trans. 2019, 358, 160-169. [CrossRef]

35. Balouiri, M.; Sadiki, M.; Ibnsouda, S.K. Methods for in vitro evaluating antimicrobial activity: A review. J. Pharm. Anal. 2016, 6, 71-79. [CrossRef]

36. Negut, A.C.; Săndulescu, O.; Popa, M.; Streinu-Cercel, A.; Alavidze, Z.; Berciu, I.; Bleotu, C.; Popa, M.I.; Chifiriuc, M.C.; StreinuCercel, A. Experimental approach for bacteriophage susceptibility testing of planktonic and sessile bacterial populations-Study protocol. Germs 2014, 4, 92-96. [CrossRef]

37. Stokes, J.M.; Lopatkin, A.J.; Lobritz, M.A.; Collins, J.J. Bacterial Metabolism and Antibiotic Efficacy. Cell Metab. 2019, 30, 251-259. [CrossRef]

38. Haque, M.A.; Imamura, R.; Brown, G.A.; Krishnamurthi, V.R.; Niyonshuti, I.I.; Marcelle, T.; Mathurin, L.E.; Chen, J.; Wang, Y. An experiment-based model quantifying antimicrobial activity of silver nanoparticles on Escherichia coli. RSC Adv. 2017, 7, 56173-56182. [CrossRef]

39. Verheust, C.; Pauwels, K.; Mahillon, J.; Helinski, D.R.; Herman, P. Contained use of Bacteriophages: Risk Assessment and Biosafety Recommendations. Appl. Biosaf. 2010, 15, 32-44. [CrossRef]

40. Pires, D.P.; Cleto, S.; Sillankorva, S.; Azeredo, J.; Lu, T.K. Genetically Engineered Phages: A Review of Advances over the Last Decade. Microbiol. Mol. Biol. Rev. 2016, 80, 523-543. [CrossRef] [PubMed]

41. Leung, Y.H.; Xu, X.; Ma, A.P.Y.; Liu, F.; Ng, A.M.C.; Shen, Z.; Gethings, L.A.; Guo, M.Y.; Djurišić, A.B.; Lee, P.K.H.; et al. Toxicity of $\mathrm{ZnO}$ and TiO2 to Escherichia coli cells. Sci. Rep. 2016, 6, 35243. [CrossRef] [PubMed]

42. DeNet, E.; Espina-Benitez, M.B.; Pitault, I.; Pollet, T.; Blaha, D.; Bolzinger, M.-A.; Rodriguez-Nava, V.; Briançon, S. Metal oxide nanoparticles for the decontamination of toxic chemical and biological compounds. Int. J. Pharm. 2020, 583, 119373. [CrossRef]

43. Katwal, R.; Kaur, H.; Sharma, G.; Naushad, M.; Pathania, D. Electrochemical synthesized copper oxide nanoparticles for enhanced photocatalytic and antimicrobial activity. J. Ind. Eng. Chem. 2015, 31, 173-184. [CrossRef]

44. Rakonjac, J.; Bennett, N.J.; Spagnuolo, J.; Gagic, D.; Russel, M. Filamentous bacteriophage: Biology, phage display and nanotechnology applications. Curr. Issues Mol. Biol. 2011, 13, 51-76.

45. Aderibigbe, A. Metal-based nanoparticles for the treatment of infectious diseases. Molecules 2017, 22, 1370. [CrossRef] 
46. Antoine, T.E.; Hadigal, S.R.; Yakoub, A.M.; Mishra, Y.K.; Bhattacharya, P.; Haddad, C.; Valyi-Nagy, T.; Adelung, R.; Prabhakar, B.S.; Shukla, D. Intravaginal zinc oxide tetrapod nanoparticles as novel immunoprotective agents against genital Herpes. Immunology 2016, 196, 4566-4575. [CrossRef] [PubMed]

47. Hang, X.; Peng, H.; Song, H.; Qi, Z.-T.; Miao, X.; Xu, W. Antiviral activity of cuprous oxide nanoparticles against Hepatitis C Virus in vitro. J. Virol. Methods 2015, 222, 150-157. [CrossRef] [PubMed]

48. Fasiku, V.O.; John, O.S.; Malima, N.M.; Hassan, D.; Revaprasadu, N. Chapter 15-Metal Oxide Nanoparticles: A Welcome Development for Targeting Bacteria. Antibiotic Materials in Healthcare; Kokkarachedu, V., Kanikireddy, V., Sadiku, R., Eds.; Academic Press: Cambridge, MA, USA, 2020; pp. 261-286.

49. Nikolova, M.P.; Chavali, M.S. Metal Oxide Nanoparticles as Biomedical Materials. Biomimetics 2020, 5, 27. [CrossRef]

50. Zhang, Q.; Chou, T.P.; Russo, B.; Jenekhe, S.A.; Cao, G. Polydisperse Aggregates of ZnO Nanocrystallites: A Method for Energy-Conversion-Efficiency Enhancement in Dye-Sensitized Solar Cells. Adv. Funct. Mater. 2008, 18, 1654-1660. [CrossRef]

51. Zhang, Q.; Chou, T.P.; Russo, B.; Jenekhe, S.A.; Cao, G. Aggregation of ZnO Nanocrystallites for High Conversion Efficiency in Dye-Sensitized Solar Cells. Angew. Chem. Int. Ed. 2008, 47, 2402-2406. [CrossRef]

52. Jassby, D.; Budarz, J.F.; Wiesner, M. Impact of Aggregate Size and Structure on the Photocatalytic Properties of TiO2and ZnO Nanoparticles. Environ. Sci. Technol. 2012, 46, 6934-6941. [CrossRef] [PubMed]

53. Gupta, J.; Bahadur, D. Defect-Mediated Reactive Oxygen Species Generation in Mg-Substituted ZnO Nanoparticles: Efficient Nanomaterials for Bacterial Inhibition and Cancer Therapy. ACS Omega 2018, 3, 2956-2965. [CrossRef]

54. Shoeb, M.; Singh, B.R.; Khan, J.A.; Khan, W.; Singh, B.N.; Singh, H.B.; Naqvi, A.H. ROS-dependent anticandidal activity of zinc oxide nanoparticles synthesized by using egg albumen as a biotemplate. Adv. Nat. Sci. Nanosci. Nanotechnol. 2013, 4. [CrossRef]

55. Singh, J.; Juneja, S.; Palsaniya, S.; Manna, A.K.; Soni, R.; Bhattacharya, J. Evidence of oxygen defects mediated enhanced photocatalytic and antibacterial performance of ZnO nanorods. Colloids Surf. B Biointerfaces 2019, 184, 110541. [CrossRef]

56. Najib, S.; Bakan, F.; Abdullayeva, N.; Bahariqushchi, R.; Kasap, S.; Franzò, G.; Sankir, M.; Sankir, N.D.; Mirabella, S.; Erdem, E. Tailoring morphology to control defect structures in $\mathrm{ZnO}$ electrodes for high-performance supercapacitor devices. Nanoscale 2020, 12, 16162-16172. [CrossRef]

57. Zhang, M.; Averseng, F.; Krafft, J.-M.; Borghetti, P.; Costentin, G.; Stankic, S. Controlled Formation of Native Defects in Ultrapure $\mathrm{ZnO}$ for the Assignment of Green Emissions to Oxygen Vacancies. J. Phys. Chem. C 2020, 124, 12696-12704. [CrossRef]

58. Meghana, S.; Kabra, P.; Chakraborty, S.; Padmavathy, N. Understanding the pathway of antibacterial activity of copper oxide nanoparticles. RSC Adv. 2015, 5, 12293-12299. [CrossRef] 